\title{
Guardians of the Land? Smallholders Living Their Nation in Interwar Finland
}

\author{
Pirjo Markkola and Ann-Catrin Östman
}

\section{INTRODUCTION}

This chapter relates small-scale landowning to lived nation by exploring what it meant to become a landowner in early twentieth-century Finland. At the beginning of the century, Finland was an agrarian country, but not all people living on agriculture owned the land they cultivated. In 1910, circa 40 percent of the agricultural population owned their farms, 20 percent were tenant farmers and 40 percent agricultural laborers, the so-called landless population, in very unstable labor relations. ${ }^{1}$ The fact that they were commonly called "landless" (in official statistics "farmless") reveals

${ }^{1}$ Arvo M. Soininen, "Maataloustilasto v. 1910 - tilasto ja todellisuus," Historiallinen Aikakauskirja 74 (1976), 211-25.

P. Markkola $(\bowtie)$

Faculty of Social Sciences, Tampere University, Tampere, Finland e-mail: pirjo.markkola@tuni.fi

A.-C. Östman

Åbo Akademi University, Turku, Finland

(C) The Author(s) 2021

V. Kivimäki et al. (eds.), Lived Nation as the History of Experiences

and Emotions in Finland, 1800-2000, Palgrave Studies in the

History of Experience, https://doi.org/10.1007/978-3-030-69882-9_8 
an ideological standpoint according to which landowning was a shared ideal, both by the educated classes and the agrarian working classes. Being landless was a problem that could be solved by becoming landowners. Various attempts to improve the living conditions of tenant farmers, cottagers and landless laborers were initiated to provide these people with their "own land," their own small-scale farms to make possible earning a living for rural working men and their families. ${ }^{2}$

Concern for agricultural interests and for a more equal division of landed property characterized the Finnish state in the interwar period, and society, composed of independent landowning farmers and smallholders, was understood to guarantee political stability. The Civil War in 1918 politicized class relations and revealed the revolutionary potential of landless laborers. The "land question" was already a key political issue before the Civil War; after the war the non-socialist governments took the issue of landowning even more seriously. Consequently, land reforms in the 1920s, 1930s and 1940s increased the predominance of smallholdings and family farms. ${ }^{3}$ The emancipation of tenant farms in 1918, in particular, strengthened the idea of landowning as a cornerstone of nationbuilding and national emotions. In 1919, the emancipation law was amended, and tenant farmers were quick to buy their farms from landowners. By the mid-1920s, two thirds of tenant farms were emancipated; and by the early 1930s, approximately 90 percent of tenant farms had

${ }^{2}$ Matti Peltonen, Talolliset ja torpparit: Vuosisadan vaibteen maatalouskysymys Suomessa (Helsinki: SHS, 1992); Matti Peltonen, "Torpparikysymys," in Suomen maatalouden historia II, ed. by Matti Peltonen (Helsinki: SKS, 2004); Ann-Catrin Östman, "Mekanisoinnin ensimmäinen aalto," in Peltonen (2004); Teppo Vihola, "Pärjääkö pienviljelys?" in Peltonen (2004); Ann-Catrin Östman, Mjölk och jord (Åbo: Åbo Akademi, 2000); Ann-Catrin Östman, "Gendered understandings of agrarian population in early Finnish social studies," in In Experts We Trust: Knowledge, Politics and Bureaucracy in Nordic Welfare States, ed. by Åsa Lundqvist \& Klaus Petersen (Odense: University Press of Southern Denmark, 2010), 249-60; Pirjo Markkola \& Ann-Catrin Östman, "Ei vain ahkeruudesta: naiset, työ ja tasaarvo," in Nälkämaasta hyvinvointivaltioksi: Suomi kehityksen kiinniottajana, ed. by Juhani Koponen \& Sakari Saaritsa (Helsinki: Gaudeamus, 2019), 167-82.

${ }^{3}$ Major reforms included the 1918 emancipation of tenant farms, the 1919 law that extended emancipation rights, land acquisition laws in 1924 and 1925, and 1936 settlement legislation. During World War II, land acquisition and settlement laws were passed. Vihola (2004), 356-65; Heikki Roiko-Jokela, "Asutustoiminnalla sodasta arkeen," in Suomen maatalouden historia III, ed. by Pirjo Markkola (Helsinki: SKS, 2004), 29-30, 37-40. 
turned into smallholdings owned by former tenant farmers or agricultural laborers. ${ }^{4}$

As in the neighboring countries, the idea of smallholding was generally emphasized. In Sweden, Denmark and Norway, gradual land reforms were introduced in the late nineteenth century, and legislation on land acquisition loans was passed at the turn of the century. After World War I, several Eastern European countries, including the newly independent Baltic States of Estonia and Latvia, carried out massive land reforms, and, accordingly, the concept of an "Agrarian reform zone" was applied by the League of Nations to the new border-states of the Soviet Union. ${ }^{5}$ Politicians and other activists in Finland were not alone in their attempts to develop agricultural policies that were expected to solve rural social problems.

Given the central importance of smallholding, the promotion of modern and rational small-scale agriculture was embedded in a network of different local associations and semi-official regional agricultural societies. Various groups of politicians and economists-socialist as well as liberal and conservative-emphasized the viability of smallholdings and worked to strengthen small-scale farming. Generally, independent farming was seen as an important tool for economic development and social cohesion, and it was often openly related to nation-building. ${ }^{6}$ As suggested in previous research, this can be conceptualized as economic nationalism, meaning "a strategy of national elites to mobilize their laboring classes politically and advance them economically" and "nation building carried out in the economic sphere." In addition to economic nationalism, small-scale agriculture was given political meaning, thus emphasizing both economic and political citizenship of smallholders. ${ }^{8}$

\footnotetext{
${ }^{4}$ Arvo Santonen, Pienviljelijäin järjestäytymiskysymys ja pienviljelijäjärjestöjen vakiintuminen Suomessa: Tutkimus maatalouden pienviljelyspoliittisesta murrosvaibeesta 1930-luvun alkuun mennessä (Helsinki: SHS, 1971), 113-14.

${ }^{5}$ Cf. Nils Edling, "Småjordbrukets tid - en inledning," Bebyggelsehistorisk Tidskrift 38 (1998), 1-5; Hans Jörgensen, "The Inter-War Land Reforms in Estonia, Finland and Bulgaria: A Comparative Study," Scandinavian Economic History Review 54:1 (2006), 64-97; Anu Mai Kõll, "Cooperatives as Part of the National Movement in the Baltic Countries," in Cooperatives in Ethnic Conflicts: Eastern Europe in the 19th and Early 20th Century, ed. by Torsten Lorenz (Berlin: Berliner Wissenschafts-Verlag, 2011), 52.

${ }^{6}$ Santonen (1971); Vihola (2004).

${ }^{7}$ The first definition by Rudolf Jaworski and the second by Àgnes Pogàny in Torsten Lorenz, "Introduction: Cooperatives in Ethnic Conflicts," in Lorenz (2011), 10.

${ }^{8}$ For examples, see Clare V.J. Griffiths, Labour and the Countryside, The Politics of Rural Britain 1918-1939 (Oxford: Oxford University Press, 2007); Piotr Wawrzeniuk, ed., Societal
} 
Also, politicians and agriculturalists involved in the Swedish movement in Finland eagerly embraced smallholding, often depicting it as a means of protecting the minority and "Swedish soil." This was a time when the idea of "Swedish-Finland," a Swedish-speaking grouping in Finland, was strengthened. In 1920, the Swedish-speaking minority amounted to 11 percent of the population (about 340,000 people). In the language act of 1922, Finnish and Swedish were declared to be national languages; however, Swedish was the national language in a minority position. Under the new language act, the Finnish municipalities were classified as unilingual (Swedish or Finnish) or as bilingual. ${ }^{9}$ The territories inhabited by Swedish speakers were intensely discussed, and some politicians used the concept of "Swedish soil" to strengthen their arguments. Consequently, agriculture and landowning were pivotal aspects of the debate. As was the case elsewhere in Finland, the explicit aim was to increase the number of smallholdings. ${ }^{10}$ The smallholding concept was propelled by economic, national and theoretical reasons, but it was openly presented in a nationalist way in the Swedish-speaking regions of Finland. ${ }^{11}$

In this chapter, we focus on encounters between smallholders and the nation by reading national agricultural policies of the 1920s "from below" in Finnish- and Swedish-speaking Finland. Encounters between smallholders and the nation took place in a variety of arenas. Civil-society organizations, aiming at improvements in family farming, formed a particularly

Change and Ideological Formation among the Rural Population of the Baltic Area 1880-1939 (Huddinge: Södertörn University College, 2008); Elizabeth B. Jones, Gender and Rural Modernity: Farm Women and the Politics of Labor in Germany, 1871-1933 (Farnham: Ashgate, 2009); Dietmar Müller \& Angela Harris, eds, Transforming Rural Societies: Agrarian Property and Agrarianism in East Central Europe in the Nineteenth and Twentieth Centuries (Innsbruck: Studien Verlag, 2010).

${ }^{9}$ Kenneth D. McRae, "Toward language equality: four democracies compared," International Journal of the Sociology of Language 187/188 (2007), 13-34; Ann-Catrin Östman, "Finnish Citizens on Swedish Soil," in Zwischen Kriegen: Nationen, Nationalismen und Geschlecterverhältnisse in Mittel- und Osteuropa 1918-1939, ed. by Johanna Gehmacher, Elizabeth Harvey \& Sophia Kemlein (Osnabrück: Deutschen Historischen Instituts Warschau, 2004), 289-303.

${ }^{10}$ Johannes Weegar, Våra fäders jord: A.B. Svenska småbruk $i$ Österbotten 1917-1980 (Vasa: A.B. Svenska småbruk, 1991); Olle Sirén, "En bondeledare och Den svenska jorden," Historiska och litteraturbistoriska studier 78 (2003), 249-318.

${ }^{11}$ Östman (2004) shows how different forms of nationalism were combined in depictions of Swedish-speaking Western Finland. Farmers were connected to citizenship in the Finnish state through their public roles, but also to Finland-Swedish ethnic nation-building through concepts like "the soil" and "the land." 
influential bridge between nationalist ideals and smallholders. Historian Henrik Stenius points out that popular movements in Finland and Sweden were more prepared "to accept standardised, statutory norms" in comparison to many other countries. ${ }^{12}$ Popular movements not only provided an arena of agency for smallholders but also taught smallholders how to verbalize emotions regarding national belonging and the virtues of citizenship. Moreover, oral histories, life stories, smallholders' letters to smallholder associations and later interviews provide us with a small corpus of ego-documents. Despite the limited size of the corpus, reading the documents in the context of economic development programs represented by civil-society organizations enhances our understanding of the smallholders living the nation in the 1920s.

Focusing mainly on encounters between smallholders and organizations providing means of modernization, we explore classed and gendered everyday practices. We ask how the smallholders utilized opportunities to keep and maintain their farms and what kind of emotions, ambitions and calculations were attached to landowning — or to losing land. In this chapter, the lived nation is studied in terms of practiced citizenship and a Koselleckian understanding of historical time as constructed in tensions between the space of experience and the horizon of expectation. ${ }^{13} \mathrm{By}$ looking at everyday social practices, we make the roles played by women and men visible and thereby study the intertwined making of gender, class and citizenship. Citizenship can be understood as a "set of practices," not just political and juridical but also economic and cultural. ${ }^{14}$ Through these practices, smallholders define themselves as competent members of society. Influenced by the work of Pierre Bourdieu, scholars have used the concept of "national habitus" to highlight the importance of everyday practices to the emotions of belonging. This approach also leaves room for local actors

${ }^{12}$ Henrik Stenius, "Nordic Associational Life in a European and an Inter-Nordic Perspective," in Nordic Associations in a European Perspective, ed. by Risto Alapuro \& Henrik Stenius (Baden-Baden: Nomos, 2010), 54-5.

${ }^{13}$ Reinhart Koselleck, Futures Past: On the Semantics of Historical Time (Cambridge, MA: The MIT Press, 1985), 267-76.

${ }^{14}$ Bryan S. Turner, "Contemporary problems in the theory of citizenship," in Citizenship and Social Theory, ed. by Bryan S. Turner (London: Sage, 1993); Anders Ahlbäck \& AnnCatrin Östman, "Inledning: Manligt medborgarskap och samhällsreformer i Finland, 1918-1960," Historiskt tidskrift för Finland 97:1 (2012), 2-16; cf. Maria Ågren, ed., Making a Living, Making a Difference (Oxford: Oxford University Press, 2017), 10-11, 127-9. 
and organizations in studies of how nations are experienced. ${ }^{15}$ Thus, situated and classed practices are in many ways fundamental to smallholders' identities, to their experiences and to feelings of belonging. The smallholders' set of practices was constructed in their daily life where their experiences and expectations shaped each other. Citizenship was practiced in a gendered way, and we study these encounters and sets of practices through exploring the importance of the family, landowning, professionalism and enacted modernity.

\section{SCEnes of ENCOUNTERS}

One of the organizations that aimed at supporting modern smallholdings was the Ruth Foundation. Founded in 1917, the Ruth Foundation was a non-socialist organization, largely characterized by ideas of social reform. Resources for the foundation were donated by a wealthy couple, commercial councilor William Ruth and his wife Fanny Ruth (née Standertskjöld), who envisioned the future of the Finnish nation being based on industrious smallholders. They were dissatisfied with the government's efforts to promote smallholding in rural Finland; moreover, they were worried about the increasing economic influence of forest-industry companies that were buying up farms from landowners. ${ }^{16}$ For the foundation, the land question was part of a social question, labeled "social policy."

The Ruth Foundation chose to work in Finnish-speaking Central Finland where large and well-developed farms were rare. It arranged training courses for smallholders and their families on a variety of topics, such as farming, cattle raising, gardening and domestic economy. It also created a prize system for model farms to promote exemplary smallholdings. In 1932, Dr. Östen Elfving, one of the major experts in modern agriculture, published the Ruth Foundation's detailed history in which he presented 20 model smallholdings, supported by the

${ }^{15}$ Cf. Andreas Stynen, Maarten Van Ginderachter \& Xosé M. Núñez Seixas, "Introduction: Emotions and everyday nationalism in modern Europe," in Emotions and everyday nationalism in modern European history, ed. by Andreas Stynen, Maarten Van Ginderachter \& Xosé M. Núñez Seixas (London: Routledge, 2020), 3-7.

${ }^{16}$ Östen Elfving, Uusia teitä pienviljelyksen kohottamiseksi: Rutbin sä̈̈döksen toiminta 1917-1932 (Porvoo: WSOY, 1932). 
foundation. Each farm description consists of a brief history, an account of family relations, key statistics on the development of agriculture and milk production as well as illustrations. ${ }^{17}$ The farm descriptions and related archival sources provide an idea of how smallholders adjusted to modernity and economic rationality in meeting the requirements of the Ruth Foundation and, thus, the requirement of the modern nation. These documents were not produced primarily by smallholders, but from a history-of-experiences angle the farm descriptions suggest how the smallholders' space of experience was crafted.

Organized voices of smallholders can also be heard from other encounters with the nation. Smallholder associations, in particular, argued that the future of the Finnish nation depended on the prosperity and wellbeing of smallholders. ${ }^{18}$ Until the mid-1920s, the Smallholders' League (Pienviljelijäin liitto) was a leading organization among the Finnishspeaking smallholders. It was a central body for social democratic smallholder associations that had been initiated by representatives of smallholders who criticized agricultural societies for acting in favor of wealthy farmers. The League was originally founded in 1910 as a central union for tenant farmers, but after the emancipation of tenant farms, it changed into the smallholders' organization in 1919. ${ }^{19}$ It provided consultation, training courses and publications as well as personal advice in correspondence with smallholders.

Another dimension of the situation of smallholders can be seen in the Swedish-speaking smallholder organizations. As elsewhere in Europe, ethnic consciousness was raised in the aftermath of World War I, and earlier bilingual organizations-among them agrarian producer co-operativeswere divided according to language. Similarly, regional agricultural societies became unilingual; one of these semi-official organizations-Österbottens

${ }^{17}$ Elfving (1932), 89-184. Manuscripts of farm descriptions are stored in the foundation's collection. There are no major differences between the typewritten manuscript and the publication. National Archives of Finland (NAF), Ruth Foundation's Collection (RFC), Folder 20, typewritten family descriptions; Model smallholdings were revisited in the 1960s and new farm descriptions were published in Veli Perttuli, Fanny ja William Ruthin sä̈̈tiö pienviljelyksen edistämiseksi 1916-1966 (Helsinki: Ruth Foundation, 1966), 110-92.

${ }^{18}$ Santonen (1971), 150-6.

${ }^{19}$ It was challenged and later outnumbered by the Smallholders' Central Union, founded in 1922 by agriculturalists in the political center and right. Vihola (2004), 378-81; Santonen (1971), 79, 119, 194; Tampere City Archives (TCA), Smallholders' League (SL). Minutes and correspondence. 
Svenska Lantbrukssällskap—was active in Ostrobothnia in Western Finland. For smallholders, it arranged ambulatory schools in villages considered underdeveloped and provided consultation and advice. ${ }^{20}$ Moreover, several organizations were responsible for running the corporation $A B$ Spenska småbruk (Swedish smallholding). The aim of this corporation was to protect monolingual Swedish communities in areas where a great majority spoke Swedish. Attracting support from other organizations, $A B$ Svenska smaibruk emphasized the threat of Finnification and offered loans to Swedish speakers to buy smallholdings. This was depicted as a way to keep Swedish soil in the right hands. ${ }^{21}$

\section{Model Farms for Rural Families}

In 1919, the secretary of the Ruth Foundation and former minister of agriculture, Mr. Uuno Brander, initiated a rewards program for model farms in Central Finland. The aim of this program was to provide local smallholders with encouraging examples of ways to improve their living conditions. In terms of economy and technology, model farms were to become modern small-scale farms run by capable and "developed" smallholders. ${ }^{22} \mathrm{Mr}$. Brander suggested that recently emancipated tenant farms should be nominated to the program because he reasoned that those farms possessed the required qualifications to develop into exemplary farming units. Location and good road communications were also used as selection criteria. Nominated smallholders were supposed to become active participants in co-operatives and other agricultural organizations, and their model farms were to receive visitors and trainees who could learn from their experiences. The co-operative movement was rather strong in Finland, and it is no wonder that the Ruth Foundation counted on cooperatives in their program. As in many other parts of Europe, cooperation had a double function: it promoted economic self-help and market integration, but it also aimed at integrating the lower strata of the population into the nation. In addition, the inclusive effects of self-help were stressed. Through edification and education, the smallholders were

\footnotetext{
${ }^{20}$ Weegar (1981); Östman (2000), 270-81.

${ }^{21}$ Sirén (2003), 249-318.

${ }^{22}$ Elfving (1932), 85; Perttuli (1966), 67-8.
} 
ascribed agency, responsibility and the political ability to act in modernized local communities. ${ }^{23}$

The Ruth Foundation did not select prosperous and well-established farms, because its aim was to promote development and progress among the lower strata of the agrarian population. Therefore, farms with barren fields and old buildings in poor condition were prioritized over modern agricultural production units. Moreover, model farms were to be mainly run by family members without hired hands. ${ }^{24}$ Family farming as a leading principle informed the selection process.

The first set of model farms was nominated in 1921 when ten former tenant farmers signed a contract with the foundation. Their farms were investigated, and a case-specific development plan was drafted. These rewards contracts, negotiated with a consultant, bound the farmers to improvements in crop rotation, the use of manure and rational forestry. Rationalized dairy farming was initiated, including the measuring and book-keeping connected with milk production. The next step was to agree on a cultivation plan with consultants. Several of the farmers were prepared to arrange cultivation experiments to improve their grain production. Moreover, repairs to cowsheds, barns, outbuildings and farmhouses were charted and planned. The construction plans for farm buildings were to be laid out by professionals and approved by the foundation's consultant. ${ }^{25}$ The consultants gave advice to the farming couple and a regular follow-up program was organized. All consultation was provided free of charge, and financial compensation was paid to model farms implementing the development plan.

Why did the smallholders join these programs and what made them willing to accept all these recommendations? It is obvious that indebted farmers of limited means were motivated by the financial benefits, but they must have also perceived other benefits in adjusting to the comprehensive development plans and progress goals suggested by the representatives of the foundation. The newly independent nation, nation-state Finland, may

${ }^{23}$ Lorenz (2011), 36-7; Mary Hilson, Pirjo Markkola \& Ann-Catrin Östman, "Introduction: co-operatives and the social question," in Co-operatives and the Social Question: The co-operative movement in northern and eastern Europe (1880-1950), ed. by Mary Hilson, Pirjo Markkola \& Ann-Catrin Östman (Cardiff: Welsh Academic Press, 2012), 8-13.

${ }^{24}$ Elfving (1932), 86; NAF, RFC, Folder 20, Manuscript of model farms.

${ }^{25}$ Elfving (1932), 87-9, Appendix II: Model contract, 209; NAF, RFC, Folder 18, Contracts. 
well have provided former tenant farmers and their families with future horizons that coincided with their own prospects as well.

The ways in which smallholders encountered the nation can to some extent be seen in those model farms joining the rewards program. In the first set of selected farms, all smallholders were former tenants who had acquired the ownership of their farms between 1909 and 1924. Almost all smallholders had a lengthy history of tenancy; only one smallholder had bought his farm from the landowner while taking over the tenant farm from his father. The men in the program were in their late 40 s or early $50 \mathrm{~s}$ (age scale 47-56), and their wives were of approximately the same age. ${ }^{26}$ Family size ranged from one foster child to 12 children (mean 5 ). The age of children varied from newborns to young adults, and some children had left their parental home to earn their own living. Two families had one old grandparent in their household; other families consisted of two generations. These families seem to represent a typical sample of tenant farmers and smallholders. ${ }^{27}$ One striking feature is the lack of young couples who might have been interested in developing into professional farmers and progressive citizens. Clearly, a lengthy experience of tenancy and future horizons of promised independence drew middle-aged smallholders to the rewards program; moreover, the foundation attempted to select experienced smallholders.

Smallholders shared a modest educational background. None of them were mentioned to have obtained a primary school education or other education. However, most couples were counted as literate or displayed other indications of being literate. The only couple that was considered weak in their written skills was mentioned to represent "a true old-school settler type." ${ }^{28}$ In comparison to the other families, it was important for the foundation to state that this family possessed other valuable characteristics. Moreover, it was clearly mentioned that all of their eight surviving children had gotten a primary school education. Regardless of their modest background, the children's education showed the parents' commitment to progress and modernization.

The second set of model-smallholding farmers was recruited in 1922-23, and their rewards program continued until the late 1920s. This

${ }^{26}$ Elfving (1932); A woman's date of birth is usually mentioned only in handwritten notes. NAF, RFC, Folder 18.

${ }^{27}$ On agricultural population, see e.g. Östman (2004), 55-73.

${ }^{28}$ Elfving (1932), 110. 
time the families were slightly smaller, and the parents somewhat younger. The mean age of the fathers was 45 and their ages ranged from 35 to 56 ; half of recruited farmers belonged to the age group of 40-44. During the rewards program, these younger families were still growing: the average increased from 3.8 children to 4.3 by the end of the program period. All model farms were small. The first set of farms was larger (mean 35.2 hectares) than the second (mean 30.8 hectares), but at the beginning of the rewards periods, the second set had slightly bigger fields than the first one. ${ }^{29}$ This suggests that the foundation turned more intensively towards cultivation than towards forestry.

\section{FAMilies of the NATion?}

The common definition of the concept of "smallholding" referred to farms which were run by family members without hired hands. Thus, family was embedded in the definition of a smallholding. The Ruth Foundation selected only families headed by a couple. In some families, married children took over the smallholding when one parent passed away or became too infirm to work. One smallholding continued to be run by a widow and her adult sons when the husband died. The size of the family as well as the balance between sons and daughters determined whether an external labor force was needed. For example, one family hired a male servant until their sons were old enough to help the parents. They had many daughters and thus no need for a female servant. ${ }^{30}$ This was in line with the principles of the foundation. For example, in 1919 the Ruth Foundation had arranged a summer course for smallholders in which one topic was the significance of a housewife and/or a daughter to a smallholder home. ${ }^{31}$ All family members were supposed to work for the smallholding, and obviously this was a daily practice.

Smallholders themselves underlined the importance of the family. In 1922, a tenant farmer turned to the Smallholders' League to seek support in gaining ownership to the fields he had previously cultivated. To prove his farming capacity and availability of labor power, he mentioned the size of his family: four sons and four daughters who were "semi-adults." Eight children needed to be fed but, more importantly, they formed the labor

\footnotetext{
${ }^{29}$ Derived from figures in Elfving (1932), 95-184.

${ }^{30}$ Elfving (1932), 110-11.

${ }^{31}$ Elfving (1932), 47.
} 
force necessary for successful farming. ${ }^{32}$ Many families participating in the Ruth Foundation's rewards program reported that they needed hired hands if their children were too young to work. As soon as the children were capable of working, the need for an external labor force could cease. In that circumstance, they indicated that they could meet the national requirements of a smallholder economy.

Life stories written by women also stress the importance of the family, and female authors point to the work done by family members. In her life story, Marta, born in 1906, describes the work done by her parents, who had bought a small farm in Ostrobothnia in the 1910s. In 1925, she and her husband bought the farm, and she explains how they managed to work together and separately. Moreover, she describes the work done by her mother, her younger siblings and her sister-in-law. ${ }^{33}$ In the 1990s, rural women in Swedish-speaking Finland and in Sweden were encouraged to write about their own lives. When depicting the interwar period farming, women repeatedly indicated what possibilities smallholding offered to the family as a unit. By using passive forms or words like "we," they referred to the family unit. In addition, they stressed the significance of working together and the work done by the family. To a high degree, Marta and the other female writers also described their work in the fields. ${ }^{34}$

The idea of family farming was strengthened by permanent and ambulatory farmers' schools and schools in domestic economy. Some of the schools, especially the ambulatory ones, were targeted at smallholders. ${ }^{35}$ In 1929, the acquisition of land was discussed in a farmers' school for smallholders in a Swedish-speaking area of Finland. It was explicitly stated that a man needs to be married in order to buy land; if a man was unmarried, he was advised to rent land. One male student boldly addressed his

${ }^{32}$ TCA, SL, Correspondence -1922. Ea:1.

${ }^{33}$ Marta's story was written after interviews made by scholars engaged in local history writing. It is a short and handwritten individual life story, encompassing five pages. Marta Nyman, letter to Ann-Catrin Östman 28 October 1994. Copy held by Östman, also The Archive of Cultural Research at Åbo Akademi University (Cultura); Ann-Catrin Östman, "Jag minns att jag var en arbetsmyra': Arbete i agrara kvinnors livshistorier," in I dialog med kvinnoliv, ed. by Harriet Silius et al. (Åbo: Åbo Akademi, 1998), 143-64.

${ }^{34}$ Östman (1998), 149-51.

${ }^{35}$ Kirsi Klemelä, Ammattikunnista ammatillisiin oppilaitoksiin: ammatillisen koulutuksen muotoutuminen Suomessa 1800-luvun alusta 1990-luvulle (Turku: Turun yliopisto, 1999); Cf. Östman (2000), 276-8. 
comrades as follows: "I would recommend that a man with experience of farming, who has some money and a family, buy land." ${ }^{36}$ The young student might have echoed his instructors, but the message certainly made sense to him and his colleagues as well.

In the interwar period, the family was the basic unit of the nation, and, in the same manner, it was the cornerstone of smallholder economy. In 1939, women's role in agriculture was described and summarized by the Board of Agriculture: "The daughters of Finland must be brought up to be housewives on these farms. The Finnish housewife must be able to take care of children, the household, the cattle and the garden, to cook, to weave, to make clothes and even to help her husband in the fields in busy times." 37 This citation, of course, reflects the standpoint of official state administration, but the mediating links between the state and smallholders, as well as life stories of smallholder women, tell a similar story with much less glory accruing to women's work in the smallholder economy.

\section{Capable Producers of the Wealthy Nation}

The aim of the Ruth Foundation was to promote smallholdings and provide smallholders with the necessary skills to cope with all aspects of the smallholder economy, from forestry to gardening and from dairy farming to rational cultivation. The smallholder economy was also of great national significance. Because the agricultural sector was important, changes in its growth had an impact on the national economy. After the hunger crisis that occurred during World War I, it was seen as necessary for the agricultural sector to meet domestic demand. ${ }^{38}$

The promotion of smallholdings carried links to agrarianism. As an ideology, agrarianism is broad-it is considered to be a theory of development in which family farms, co-operatives and municipal self-government constitute the central elements. At its core is an emphasis on the idea of

\footnotetext{
${ }^{36} \mathrm{NAF}$, Österbottens svenska lantbrukssällskap (ÖSL) UA 1, 8 January 1929.

${ }^{37}$ Department of Domestic Science in the Board of Agriculture, ed., Maataloudellinen kotitalousopetus: Oppilaitokset, harjoittelu, neuvonta [Teaching of Rural Domestic Science. Schools, Training, Travelling instructors] (Porvoo: WSOY, 1939).

${ }^{38}$ Teppo Vihola, "Maatalouden rakennemuutokset itsenäisessä Suomessa," in Peltonen (2004), 330-51; Jari Ojala, "Feeding economic growth: agriculture," in The Road to Prosperity: An Economic History of Finland, ed. by Jari Ojala et al. (Helsinki: SKS, 2006), 78-84.
} 
the "middle way," a form of social reform and economic development positioned between liberalism and socialism. In the interwar period, many agrarian movements in the Eastern European countries were leftist, with an emphasis on economic, social and democratic reform. ${ }^{39}$ At the same time, there was competition for the minds of smallholders in Finland. Not only Social Democrats and the Agrarian Party but also communists and other political small groups tried to recruit smallholders to their rank and file. ${ }^{40}$

The Ruth Foundation and the smallholder associations stressed the connection between economy and politics. Societal progress, economic development and the rationalization of agriculture were key goals. Smallholding was not just characterized as a tool for improving the economy of individuals and families; it also gave nations-especially the Swedish minority-tools for self-defense and self-protection, as the foundation of $A B$ Svenska småbruk indicates. ${ }^{41}$ Moreover, a stronger smallholder economy with independent and progressive smallholders served the national economy and provided Finnish consumers with locally produced milk products, eggs, vegetables and grain. Co-operative dairies and other forms of agricultural co-operation facilitated smallholders' contributions to the national economy. Thus, smallholders' willingness to increase their production showed their commitment to national efforts as well. ${ }^{42}$

This endeavor was shared by politicians, civil-society activists and smallholders themselves. The same tenant farmer who referred to his large family when turning to the Smallholders' League also made a reference to his schooling. He had gone to a farmers' school; moreover, he was a trained forest warden (ranger), and he considered his 15 years of experience in farming as extensive. Another man reported that he had had several decades of experience on his tenant farm, and, for a third farmer, it was crucial to underline his 25-year contract signed eight years before. The fact that one tenant farmer stated in his letter that he was a member of the Smallholders' League can also be read as evidence

\footnotetext{
${ }^{39}$ Johan Eellend, "Agrarianism and modernization in inter-war Eastern Europe," in Wawrzeniuk (2008), 35-6; Cf. Jörgensen (2006), 64-97.

${ }^{40}$ Matti Lackman, Taistelu talonpojasta: Suomen Kommunistisen Puolueen subde talonpoikaiskysymykseen ja talonpoikaisliikkeisiin 1918-1939 (Oulu: Pohjoinen, 1985), 86-89; Santonen (1971), 123-7.

${ }^{41}$ For Nordic examples, see Edling (1998). Cf. Eellend (2008).

${ }^{42}$ Cf. Lorenz (2011), 27-9.
} 
of a serious attitude towards professional farming. ${ }^{43}$ Experience, knowledge and stability were characteristics often invoked when tenant farmers tried to prove that they were economically worthy citizens and reliable smallholders.

The smallholders' interpretation of professional farming was based on their space of experience which sometimes clashed with the guidelines of the supervising organizations. One smallholder considered the Ruth Foundation's construction plans for a stone cowshed too expensive and unsuitable for a smallholding. Instead, he built a wooden cowshed on a concrete foundation. ${ }^{4}$ Differing views on smallholder economy also became evident when the foundation was not satisfied with one smallholder's input. The smallholder, who had worked as a foreman in a large farm, applied his know-how and experience to his own small-scale agriculture. The Ruth Foundation considered the progress of this smallholding too modest and claimed that the smallholder's working methods were unsuitable for a smallholding. For example, the cattle were too numerous compared to the size of the fields and the old-fashioned cowshed was not replaced until 1952. ${ }^{45}$ It is more than possible that, due to his experience as a farm foreman, this smallholder was not as receptive to all aspects of consultation as were some others.

Some smallholders explicitly stated their commitment to professional development. In his letter to the Ruth Foundation, Aapo Hietamäki tried to speed up his first cultivation plan and inquired if the promised consultant was already coming to Hietamäki's farm. It would soon be time for spring sowing and the smallholder indicated his immediate need of consultation. A similar wish was expressed by another smallholder. For these farmers, the foundation represented useful professional support. Some smallholders reported their purchase of professional literature, and one group of smallholders and their wives even sent a telegram to the Ruth Foundation to express their gratitude for an agricultural excursion that had been arranged for them. ${ }^{46}$ Becoming better and more knowledgeable smallholders was one way to live the nation in a smallholder economy.

${ }^{43}$ TCA, SL Ea:1, Correspondence -1922 .

${ }^{44}$ The cowshed was later approved by the foundation. Perttuli (1966), 170.

${ }^{45}$ Elfving (1932), 155-6. In the 1960s, this smallholder was posthumously depicted as an eager participant in excursions, exhibitions and training courses. Perttuli (1966), 186-8.

${ }^{46} \mathrm{NAF}, \mathrm{RFC}$, Folder 8, letter from Aapo Hietamäki to consultant Vänttinen, 29 April 1921; Folder 18, letter from Asarias Joenniemi to consultant Vänttinen, 9 May 1924. 
The Ruth Foundation met the needs of the smallholder economy by hiring a household consultant to give advice on gardening, and their professional milkmaid recommended better winter forage. Gender-specific tasks for men included improvements in forestry, drafted and planned in the rewards program. To serve their members, many local smallholder associations eagerly invited household and dairy farming consultants provided by their central organization. ${ }^{47}$ Here, again, smallholders' space of experience was negotiated with educators. This guidance can be regarded as an attempt to strengthen the position of rural women and modernize the gendered division of labor. Women needed education in dairy farming, but at the same time they were supposed to have time for domestic duties, such as gardening. ${ }^{48}$ The gendered forms of consultation both relied on the experiences of smallholders and tried to transform modern smallholder experiences.

All smallholder organizations focused on the need to improve living conditions. When schools for smallholders were planned, a lack of modern know-how as well as harmful conservatism were pointed at. It was especially in remote areas where farming did not meet the standards of developing societies. Learning by observation and socialization no longer sufficed; in other words, the smallholders' space of experience and horizons of expectation needed to change. Ambulatory schools for youth living in peripheral villages would provide the necessary practical and theoretical education in farming methods and in questions of economy. Moreover, it was commonly feared that young people, in particular, found urban and industrial centers more attractive than rural areas and farm labor. ${ }^{49}$

In early twentieth-century Finland, dairying was considered extremely important in economic terms; simultaneously it was characterized as a female industry. Some discussions by students in ambulatory schools stated that old-fashioned men did not understand the importance of dairying. Clearly, men were seen as needing to change, something that could be achieved through education and supervision. Discussions on this topic

${ }^{47}$ Elfving (1932), 89-91; The smallholders' League employed visiting consultants. Member associations were entitled to invite them. TCA, SL Ea:1, Correspondence -1922.

${ }^{48}$ Ann-Catrin Östman, "Civilizing and mobilizing the peasantry," in Hilson, Markkola \& Östman (2012), 126-35.

${ }^{49} \mathrm{NAF}$, ÖSL, He 3, Amb. Lantmanna- och småbrukarskola; Anna Halme, Eteen eestä ihanteen: Kansanopistoelämää Lahdessa 1893-1939 (Helsinki: Kansanvalistusseura, 2003). 
were popular and sometimes intense. The same tone can be found in interviews with former participants of the Ruth Foundation's rewards program. One farmer criticized his father for neglecting the improvements in dairy farming recommended by the foundation. Another farmer admitted in the 1960s that his wife and the foundation had been right when they suggested investing in a proper cowshed; and one smallholder's wife explained how her husband did not always understand recommendations for cattle keeping. ${ }^{50}$ These later interpretations bring out generational and gendered tensions otherwise quite hidden in the farm descriptions published in 1932.

The popularity of ambulatory farmers' schools and domestic economy classes is one indication that instruction and consultation in the smallholder economy was a crucial way for smallholders to become professional farmers. This seems to have been a source of pride. In everyday work practices, the smallholders proved themselves modern and rational and thus able to practice their nation. These prescribed practices signaled and enforced understanding of modernity and progress. ${ }^{51}$ Women attended courses in dairy farming, cattle keeping, poultry keeping and food preservation, and men received training in field work, farming technology and forestry. Quite typically, these ambulatory classes organized patriotic celebrations at the end of the classes. Their program consisted of songs, poems and presentations with an explicit nationalist message. For example, at the end of the first awards program, the Ruth Foundation invited smallholders to a festive celebration in the nearby city of Jyväskylä. Both spouses attended the closing ceremony in which leading agricultural specialists gave talks on the national importance of smallholding. ${ }^{52}$

\section{Performing Progressive and Modern Citizenship}

Progress and development were made an explicit goal of the Ruth Foundation, and the civic duties of smallholders are reported in its documents. The previously mentioned smallholder Aapo Heinämäki was an

${ }^{50}$ NAF, RFC, Folder 18; Perttuli (1966), 122, 128, 188.

${ }^{51}$ Cf. Turner (1993). E.g. Östman (2004); Deborah Fitzgerald, “Accounting for Change: Farmers and the Modernizing State," in The Countryside in the Age of the Modern State, Political Histories of Rural America, ed. by Catherine McNocil Stock \& Robert D. Johnston (London: Cornell University Press, 2001), 189-212.

${ }^{52}$ NAF, RFC, Folder 18. Smallholder celebration in Jyväskylä 1926. 
exemplary citizen in his local community: he was repeatedly elected to the municipal council; he belonged to several municipal boards and the board of cooperative store; moreover, he ran a local cooperative bank for six years. ${ }^{53}$ Another smallholder chaired the local board for poor relief, belonged to many other municipal boards, was an elected member of the municipal council and chaired the board of a cooperative bank. ${ }^{54}$ Several other smallholders from the model farms reported their local positions of trust.

In the same way, many local associations indicated smallholders' commitment to progressive citizenship. Smallholder associations supported smallholders' participation in local elections and organized training courses in civic duties. ${ }^{55}$ The Smallholders' League published a journal called Pienviljelijä (Smallholder). Local chapters of the league distributed the journal, and some chapters even reflected upon the significance of educational publications. Many local associations organized their own libraries in which they collected useful literature not only on various aspects of smallholder economy, such as field cultivation, cattle keeping, poultry keeping, gardening and forestry, but also on the national role of citizens ${ }^{56}$ Here smallholders were building on a lengthy civil-society tradition since the late nineteenth century. Village libraries and local study circles had been organized by the temperance movement, the labor movement and agrarian civic organizations. ${ }^{57}$

The Ruth Foundation's aim of promoting progress and modernization met with some response in the families of the model farms. For them, children's primary school education was common. At least six children were sent to vocational schools: three boys were supported by the foundation to go to the farmers' school, two girls went to a school in dairy farming, and one girl studied in a folk high school. Figures may be even higher since many families in the second set of model farms still had small children. Nevertheless, professional consultation received by parents and the education given to children showed that the educational aims of the foundation met the needs of smallholder families. In the 1960s, one of the boys who went to the farmers' school reminisced about his education and

${ }^{53}$ NAF, RFC, Folder 18. Note on Heinämäki farm.

${ }^{54} \mathrm{NAF}, \mathrm{RFC}$, Folder 18. Note on Kuivakangas farm.

${ }^{55}$ Santonen (1971), 150-6.

${ }^{56}$ E.g. TCA, SL Cd:2, Minutes of Vihdin Herrakunnan torppariosasto 4 July 1920.

${ }^{57}$ Risto Alapuro \& Henrik Stenius, "Kansanliikkeet loivat kansakunnan," in Kansa liikkeessä, ed. by. Risto Alapuro et al. (Helsinki: Kirjayhtymä, 1987); Hilson, Markkola \& Östman (2012), 8-14. 
stated its significance not only to farming but also to civic duties in local society. ${ }^{58}$ Professionalization of farming was a crucial part of nationbuilding both from above and from below.

Reading was a civic virtue. By reading books, rural people were to learn how to become proper citizens. ${ }^{59}$ In the written contracts, smallholder families were to acquire vocational literature on agriculture. The smallholder's guide and a calendar on agriculture were often mentioned in the contract, and the co-operative movement's journal was highly recommended. Documents from farm inspections reveal that many families actually bought recommended advisory material, whereas some other families were not willing to invest in such literature. Usually families with a basic library received more positive comments on the state of farming than families without books and journals. ${ }^{60}$ Owning and reading books was a crucial part of a smallholder's citizenship.

The watchword being "progress," societal progress, economic development and rationalization of agriculture were key aspects that framed the discussions and arguments in courses for smallholders. The smallholders needed education in rational methods. The concept of "rational" could mean anything from working according to the latest scientifically proven methods in the various fields of agriculture to applying those results in the running of the household and in nutrition. It was also emphasized that the schools should discuss a range of themes, such as health care, municipal activities and temperance. All these aspects were touched upon when students were discussing the need of societies for control of cows and their milk. The educators and teachers encouraged smallholders to form voluntary "control-organizations," which would hire a trained woman to visit and control cattle feeding and the quality of the milk. ${ }^{61}$ Thus, there were no lines drawn between public activities and work practices.

${ }^{58}$ Elfving (1932); Paavo Saarinen, b. 1909, son of Sakari and Tiina Saarinen from the first awards program was interviewed by Veli Perttuli (1966), 145.

${ }^{59}$ Saara Tuomaala, "Pulpeteista pihoille, metsiin ja kaduille," in Valistus ja koulunpenkki: Kasvatus ja koulutus Suomessa 1860-luvulta 1960-luvulle, ed. by Anja Heikkinen \& Pirkko Leino-Kaukiainen (Helsinki: SKS, 2011), 355-65; Saara Tuomaala, Työtätekevistä küsistä pubtaiksi ja kirjoittaviksi: suomalaisen oppivelvollisuuskoulun ja maalaislasten kohtaaminen 1921-1939 (Helsinki: SKS, 2004).

${ }^{60} \mathrm{NAF}, \mathrm{RFC}$, Folder 18. Inspections.

${ }^{61}$ Jakobstad-Pietarsaari Museum, Archives: Mellersta Österbottens vandrande folkhögskola, 10 April 1935, 17 August 1935; Cf. Östman (2000), 265-7. 
The Ruth Foundation also encouraged families to join controlorganizations. Altogether 55 percent of the model farms joined a controlorganization, and the figure could have been higher if there had been more local organizations to promote dairy farming. ${ }^{62}$ Given the remote location of selected farms, this was a high figure. Discussions at farmers' schools also reveal an understanding of the necessity for participation in civic life-it was emphasized that the farmers should establish organizations for the wellbeing of the community. Daily practices, such as bringing milk to the co-operative dairy and keeping the cows as well as the cowshed clean, were also central to the construction of identity and national belonging. ${ }^{63}$ It was through everyday practices and the routines of daily work that identity was formed and performed. This connects to wider debates about the construction of the nation in practices and daily life as well as to understandings of performativity. ${ }^{64}$

This is closely linked to the idea that modern practices serve to construct a healthy community where women and men are ascribed modernized and partly similar roles. Thus, rational and modern practices bridged the understandings of private and local as well as of municipal and national. Tending the farm and participating in agricultural organizations and local administration served as the practice of commitment to the nation and the community. Also, in this way, the nation was practiced.

\section{HUNGER FOR LAND}

The Ruth Foundation supported smallholders who had emancipated or were about to emancipate their tenant farm. Landowning was an obvious goal for many tenant farmers and cottagers. However, not all of them emphasized ownership. For example, while one rural workers' association was transformed into a smallholders' association in 1920, their new statutes defined a permanent right of residence and a permanent right to cultivate the farm as their goal. ${ }^{65}$ This was in keeping with the previous social democratic smallholder movement which struggled between the ideals of collectivization and private ownership. The position of the

${ }^{62}$ Elfving (1932).

${ }^{63}$ Cf. Östman (2012).

${ }^{64} \mathrm{Cf}$. The introduction of the book.

${ }^{65}$ TCA, SL Ce:2, Minutes of Majaalahden työväenyhdistys 1 September 1920. This decision followed the central oganization's policy. 
landless population, including tenant farmers, was one of the most burning domestic political concerns in Finland. For the labor movement, applying international socialist theories to the agrarian realities of Finland was a difficult equation to solve. After the parliamentary reform in 1906, landless people voted for Social Democrats; at the same time, they wanted to become landowners. In the 1910s, the Social Democratic Party adopted a pragmatic stance on promoting emancipation of tenant farms and gained massive electoral support in the countryside. Later, their party program in 1922 took a positive stance on private (small-scale) landowning and independent smallholdings. ${ }^{66}$

Families participating in the Ruth Foundation's rewards programs showed an explicit hunger for land. Some of those families had started from scratch: for example, from a cultivated area of 0.02 or 0.1 hectares, a dilapidated cottage and no forestland. ${ }^{67}$ In general, during the rewards period, the first set of model farms increased their average arable land from 5.8 to 6.2 hectares, and the second set increased theirs from 6.2 to 7.1 hectares. However, this growth tells only a partial truth about smallholders' industriousness. Those smallholders who had started almost without fields had cleared their $4-5$ hectares before the program, and the rewards period represented just a cross-section of their agricultural expansion. ${ }^{68}$ Some smallholders could also afford to buy meadows, marshes and forestland to be cleared and cultivated.

Families with a migration background provide another example of the smallholders' hunger for land. One couple (born in 1872 and 1881) had lived for a long time in the United States where the husband worked as a tailor. After their return to Finland in 1910, they settled into a tenant farm of 42 hectares and bought it in 1919. By the mid-1920s they had more than doubled the farm's arable land from 7 to 17 hectares. In another family, the husband had worked in Canada and the United States as a lumber jack and a sawmill worker. After his return to Finland, he was gradually able to acquire landed property. In 1906, he and his wife first bought a right of tenancy, and in 1916 their tenant farm was emancipated. Some years later, they more than doubled the total area to 42 hectares. ${ }^{69}$

\footnotetext{
${ }^{66}$ Petri Jussila, Tilastomies torpparien asialla: Edvard Gyllingin maatalouspoliittinen ajattelu ja toiminta suurlakon ja sisällissodan välissä (Helsinki: THPTS, 2015), 250-2; Santonen (1971), 128-9; Lackman (1985), 46.

${ }^{67}$ Elfving (1932), 105, 190.

${ }^{68}$ E.g. Sahinaho, Lahdenmäki and Peltola smallholdings. Elfving (1932), 165-81.

${ }^{69}$ Elfving (1932), 127, 136.
} 
It is probably not surprising that families with experiences of migration had acquired the resources to become landowners; moreover, they were willing to raise their status by joining a farming development program.

Owning land was not enough. The farm needed to be self-sufficient and either free of debt or with the debt under control. Emigration was actually often a conscious attempt to stick to the land. Marta's husband emigrated to Canada in order to earn money to pay their debts. In the short life story written by Marta, landowning is ascribed a pivotal role. She depicts the tenant farm where she was born and relates how her parents bought land. Moreover, she also emphasizes how she and her husband worked hard when they acquired this piece of land. In her life story, the focus is clearly on the tenant farm. ${ }^{70}$ Collective conventions form life writing and writing a life story is a way of organizing and making sense of experiences. ${ }^{71}$ Marta's other texts, her answers to questionnaires, also emphasize the work on the farm and, eventually, the love for the land. ${ }^{72}$ The short life story reveals that the key topics are related to the small farm, for which Marta carried responsibility. Like other forms of life writing, this text bears value.

The reputation of the Ruth Foundation gave hope to landless people who were hungry for their own piece of land. In 1918, for instance, the foundation received a letter from Lapland with a polite question as to whether the foundation's funds were available, either as loans or as donations, to agricultural workers interested in buying a smallholding. The foundation, however, recommended that this man turn to the National Board for Rural Settlement. ${ }^{73}$

Among the smallholders selected by the Ruth Foundation, we can find some unfortunate families. For example, one farm had been run by a tenant widow and her daughters until one daughter's husband took over the tenant farm. Buildings were dilapidated and the badly kept arable land was barren. In the 1920s, a proper farmhouse was built following the construction plans provided by the foundation. A cowshed and other animal shelters were rebuilt as well. Attempts to develop farming

${ }^{70}$ Cultura. Marta Nyman 8 October 1994, 1, 3-4.

${ }^{71}$ Lena Marander-Eklund \& Ann-Catrin Östman, "Biografiska betydelser," in Biografiska betydelser - norm och erfarenheter i levnadsberättelser, ed. by Lena Marander-Eklund \& AnnCatrin Östman (Hedemora: Gidlunds förlag, 2011), 10-14.

${ }^{72}$ The Society of Swedish Literature in Finland Archives (SLS) 1210: Utvandrarna, 566-79.

${ }^{73}$ E.g. NAF, RFC, Folder 8. Letter from Aatu Hulkko to the foundation 7 September 1918, letter from the foundation to Aatu Hulkko in November 1918. 
and make it profitable through the awards program are obvious; the importance of the rewards program is further confirmed by the fact that the farm again got into financial difficulties soon after the program period. In 1932, this indebted smallholder passed away and his estate had to sell the farm to pay his debts. ${ }^{74}$ Attempts to stick to farming with the help of a development program indicate that losing the land was a threat to be taken seriously.

Marta's husband emigrated so that the couple could pay for their farm. Throughout the years, Marta took care of the farm and the children. Life as smallholder was difficult. When a collection of rural life stories was organized, the writers stressed the experiences of smallholding. "We in Ostrobothnia were smallholders. Had 5-7 cows on the farms, 1-2 horses, sheep and hens and some 8-10 goats," summarized a woman of her community. ${ }^{75}$ Several authors from the group underline that smallholding was the normal state of affairs in Ostrobothnia. Scholars of rural autobiographies stress that one needed a motive to write. Certain features in the narratives tend to surface more often than others, among them stories of hardship or poverty, and these accounts are often directed to an audience of younger generations. ${ }^{76}$ Furthermore, the women who answered the call for life writing referred to the experiences of emigration, and, like Marta, they depicted the hard lives of their mothers and other women, who took on responsibility for farming, while their men-husbands and brothersworked abroad. These writers chose to make the shared and collective experiences visible when writing about their own lives. While official texts spoke the language of progress, economic stability and civic development, these texts tell stories of hardships. Hunger for land led to hard work, sometimes too hard, and these stories reveal the other side of the coin.

\footnotetext{
${ }^{74}$ According to a later interview, the kind-hearted smallholder had secured other farmers' loans and was therefore indebted. Perttuli (1966), 129.

${ }^{75}$ Östman (2000), 34.

${ }^{76}$ Cf. Eija Stark, "Narrative Weapons of the Underprivileged," Ethnologica Scandinavica 44 (2014), 23-38.
} 


\section{CONCLUSION}

You who go to Finland to look for things worth seeing, do not forget the best of them all, the brave housewife and the great work which is being done everywhere in order to improve the Finnish home, to strengthen domestic happiness and to create an unfaltering love for their native country. ${ }^{77}$

In 1939, the Department of Domestic Science in the Board of Agriculture published a richly illustrated book telling of the achievements of domestic science in Finland. The book was targeted at international visitors in the 1940 Summer Olympics in Helsinki. Due to the war, the Olympics were canceled, but the book on domestic science remains and explicates the bond between women's work, home and emotions of national belonging that were developed during the interwar period. Women in the above-mentioned smallholder families who received consultation in cattle keeping, gardening and domestic duties were now depicted as the foremost tourist attraction in Finland.

Our case study investigates smallholding not only as an ideology but also as practiced, lived and promoted. It enables us to uncover interaction and encounters between smallholders and social reformers as well as agriculturalists. More importantly, it provides insights into how seemingly trivial everyday practices, such as feeding the animals, clearing land for cultivation and tending the garden, were given added value and interpreted in terms of professionalism and progress.

In many parts of Europe, nationalist movements idealized the peasantry. In Finland, too, smallholders were considered the pillar of Finnishness as well as of the "Finland-Swedish" ethnicity. Nonetheless, ambivalent and classed understandings of the peasantry prevailed. In this context, economists, politicians and civil-society organizations together with the agrarian population engaged in developing and improving the status of smallholders. Both the Ruth Foundation, the Swedish-speaking consultants and the social democratic smallholder associations operated in geographical areas considered peripheral and underdeveloped. Documents from these organizations make visible understandings and definitions of rural problems as well as encounters with smallholders.

These encounters reveal smallholders' responses to agricultural policies. Smallholders were hungry for land, and in that hunger, they needed both

${ }^{77}$ Maataloudellinen kotitalousopetus (1939), 1. 
material and immaterial resources. The ideas of proper farming patterns and family relations, represented by organizations and smallholders, clashed, challenged and reinforced each other. The ideals of national progress were negotiated in these encounters. People living on small-scale agriculture accepted and adapted to the ideals of nation-building through rationalization of agriculture and dairy farming, but to some extent they also resisted middle-class values coming from above. Koselleck's conceptualization of historical time ${ }^{78}$ suggests that the space of experience and the horizon of expectation informed the ways in which individual smallholders selected elements of consultation. For example, if they felt that a cultivation plan made sense to them or met at least some of their expectations, it was accepted; if a suggested cowshed seemed too expensive, it was rejected. However, the selective nature was gendered, and tensions between generations were also present in smallholder economy.

Economic activities and everyday practices were both gendered and classed. Smallholders and civic activists understood that smallholding was a family issue; it was often stated that the work of the whole family-husband, wife and children-was needed to secure the progress and viability of small farms. Women were not only practitioners of home economics but were also engaged in agriculture in an informed way. Many smallholders turned into active citizens who pursued both economic and political citizenship as producers and participants in municipal administration, cooperatives and associations. The citizenship formed, formulated and practiced was often male. However, women were also ascribed civic duties, and these responsibilities are noticed in life writings. The organizations formed by the farmers themselves were especially pivotal, and the dairy organizations in particular operated in both private and public spaces.

By tracing the voices of the smallholders, we can point at understandings of smallholding as modern and progressive as well as an appreciation of landowning. Aspects related to progress and professionalism are explicitly and implicitly stressed in ego-documents. The smallholders performed the practices, and understood the rationality, of modernization. However, ego-documents also enable a more complex picture and render the harshness of smallholding livelihoods visible.

In this chapter, we have focused on practices. However, our reading suggests that the concept of land is emotionally and symbolically charged when alluding to the nation. Both in Finnish and in Swedish "land" can

${ }^{78}$ Koselleck (1985), 272. 
be related to soil, ground and country. Thus, the theoretical concept of emotive, referring to certain kinds of emotional statements that show how words, tropes, and figures both form, change, and use emotions, would be a fruitful way to further conceptualize the ways in which smallholders lived their nation. ${ }^{79}$ To a high degree, terms like land (maa, land/jord) and agriculture (maanviljely, jordbruk) could be understood as emotives. In particular the first pair of words (maa/jord) could be used in a symbolic way but also in connection to concrete farming and to everyday work practices. This conceptualization, however, would need a different reading of this material, complemented by a wider set of publications by smallholder organizations.

After all, women and men who encountered these organizations believed in the possibilities of smallholding. Besides depicted love of their farmland, an emphasis on hardship and misery is visible in some life stories, maybe as an effect of a dialogue with later generations or as an implicit critique of the promises and belief promoted by other groups. Read in this way, these texts bear witness to and comment on ideals formed by "cruel optimism," a concept presented by Lauren Berlant to depict societal promises which were never fulfilled ${ }^{80}$ After World War II, the prospects of Finnish smallholders were first to be fueled by new land reforms and then crushed by a society in which smallholdings were no longer viable. The tension between the horizon of expectations encouraged in the interwar period and the space of experience of post-World War II smallholders was dramatically altered.

${ }^{79}$ William M. Reddy, "Against Constructionism: The Historical Ethnography of Emotions," Current Anthropology 38:3 (1997), 331.

${ }^{80}$ Lauren Berlant, Cruel Optimism (Durham: Duke University Press, 2011), 23-4. 
Open Access This chapter is licensed under the terms of the Creative Commons Attribution 4.0 International License (http://creativecommons.org/licenses/ by $/ 4.0 /$ ), which permits use, sharing, adaptation, distribution and reproduction in any medium or format, as long as you give appropriate credit to the original author(s) and the source, provide a link to the Creative Commons licence and indicate if changes were made.

The images or other third party material in this chapter are included in the chapter's Creative Commons licence, unless indicated otherwise in a credit line to the material. If material is not included in the chapter's Creative Commons licence and your intended use is not permitted by statutory regulation or exceeds the permitted use, you will need to obtain permission directly from the copyright holder.

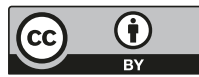

